\title{
PENGARUH BERBAGAI MEDIA TANAM TERHADAP PERTUMBUHAN DAN PRODUKSI BEBERAPA NARIETAS TANAMAN JAGUNG(Zea mayz $L$ )
}

Muhammad Yunus ${ }^{1}$, muhammad Arafah., SP,MP ${ }^{2}$ Aswin Bovita., SP ${ }^{2}$

Perogram setudi Agroteknologi Fakultas Pertanian Universitas islam Indragiri

\begin{abstract}
Abstrak
tentang pengaruh media tanam terhadap pertumbuhan dan berbagai pruduksi beberpa variatas tanaman jagung (zea mayz L). di laksanakan di bulan febuari sampai juni 2012, yqng bertempat di desa kota baru kecamatan keritang kabupaten indra giri hilir provinsi riau. Penilitian ini mengunakan rancangan acak lengkap (RAL) yang di susun secara faktorial yang terdiri dari 2 faktor 3 ulangan. Faktor $T$ adalah tanah yang terdiri dari 3 taraf yaitu T1 (tanah gambut), T2 (tanah PMK) T3 (tanah Aluvial), sedangkan faktor $V$ adalah varietas yang terdiri dari 4 taraf yaitu V1 (jagung manis), V2 (NT 10), dan V3(N35) dan V4 (mitro).

Hasil penelitian menunjukan bahwa intraksi media tanam dan varietas berpengaruh tidak hanya terhadap semua paramenter yang di amati. Untuk perlakuan media tanam secara tunggal berpengaeuh nyata terhadap luas daun,diameter tongkol, akan tetapi berbeda berbeda tidak nyata dengan tinggi tanaman, umur berbunga, jumlah biji pertongkol, pruoduksi jagung kering pipialan per tanaman dan berat 1000 bijii. Tanah terbaik pada penelitian ini adalah tanah aluvial. Sedangakan perlakuan varietas secara tunggal berpengaruh nyata terhadap tinggi tanaman, umur berbunga, diameter tongkol, jumlah biji pertongkol dan peroduksi kering jagung pipilan per tanaman serta bobot 1000 biji. Varietas terbaik di peroleh pada varietas mitro.
\end{abstract}

Kata kunci : media tanam, varietas, pertumbuhan dan produksi.

Abstract
about the influence of the planting media on the growth and various production of
some maize varieties (zea mayz L). carried out in February to June 2012, which is located in
the village of the new town of Keritang sub-district of Indra Giri downstream of Riau
Province. This research uses a completely randomized design (CRD) compiled factorially
consisting of 2 factors 3 replications. The T factor is soil consisting of 3 levels namely T1
(peat soil), T2 (PMK soil) T3 (Alluvial soil), while factor V is a variety consisting of 4 levels
namely V1 (sweet corn), V2 (NT 10), and V3 (N35) and V4 (mitro).
The results showed that the intraction of planting media and varieties affected not
only all the parameters observed. For single planting media treatment significantly affected
leaf area, ear diameter, but not significantly different from plant height, flowering age,
number of seeds perongkol, production of dry corn pipial per plant and weight of 1000 seeds.
The best soil in this study is alluvial soil. While the treatment of single varieties significantly
affected plant height, flowering age, ear diameter, number of seeds perongkol and dry
shelled corn per plant and weight of 1000 seeds. The best varieties are obtained from the
mitro varieties.
Keywords: Planting Media, Varieties, growth and production

\section{Pendahuluan}

Jagung merupakan bahan pangan kedua setelah padi, di indonisia selainitu juga 
jaguang di gunakan sebagai bahan baku industri pakan dan industri lainya. Sering bertambahnya jumlah penduduk mengakibatkan permintaan jagung di dalam negeri terus meningkat dari tahun ke tahun. Untuk memenuhinya di perlukan langkah peningakatan peruduksi jagung (Rukmana, 1997).

Produksi lagung 2010 (ATAP) sebesar 41.82 ton ppipilan kering, atau menurun sebesar 25,94 persen di bandingkan tahun 2009 dengan tingkat produksi 23,20 kuintal per hektar (turun 2,68 persen) dan luas panen sebesar 18.044 hektar (turu 27,87 persen). Produksi jagung tahun 2011 (angka ramalan II) di perkirakan sebesar 37,219 ton pipilan kering atau turun 4.634 ton (11.09 persen) di bandingkan produksi jagung tahun 2010. Hal ini diperkirakan karena menurunya luas panen jagung sebesar 2.07 hektar (11,50 persen) (badan pusat stastik(2012),

Masih rendahnya produksi jagung $d$ sebabkan belum meluasnys penggunaan varietas unggul, minimnya permodalan petani, serta pemakaian pupuk dan cara bercocok tanam yang kurang memenuhu anjuran (Suprapto, 2012). Padahal pemakaian benih berkualitas unggul dapat memberikan hasil yang sangat baik. Faktor lingkungan juga mempengaruhi fungsi fisiologis dan morfologi tanaman. Produksi jagung per satuan luas selalau tergantung kepada varietas tanaman.

Tanaman jagung dapat di tanam sepanjang tahun, lahan yang sesuai untuk tanaman jagung tersedia sangat luas seperti lahan kering, sawah tadah hujan ,lahan gambut, lahan pasang surut dan lahan lebak. Pemanfaatan berbagai jenis tanah untuk budidaya tanaman jagung perlu ditingkatkan, mengingat makin tinginya permintaan akaan produksi jagung. Pengunaan tanah seperti tanah gambut, tanah aluvial dan tanah podzolik merah kuning (PMK).

Tanah adalah suatu benda alami yang terdapat di permukaan kulit bumi, yang tersusun dari bahan-bahan mineral yang hasil pelapukan batuan dan bahan organik berasal dari pelaoukan tumbuhan dan hewan, yang merupakan medium pertumbuhan tanaman dengan sifat-sipat tertentu yang terjadi akibat gabungan dari faktor iklim, bahan induk, jasad hidup, bentuk wilayah dan lamanya pembentukan (Sarief.1986).

Faktor produksi yang penting dalam menjunjung produk pertanian adalah tanah. Peranan tanah sebagai alat produksi pertanian adalah;1) tanah sebagai tempat berdirinya tanaman;2) tanah sebagai tempat unsur-unsur hara yang diperlukan tanaman;3) tanah sebagai tempat persediaan bagi air tanaman dan 4) tanah dengan tata udara yang baik merupakan lingkungan yang baik bagi pertumbuhan tanaman.

memiliki $\mathrm{pH}$ yang rendah antara 4-5,5, oleh sebab itu teknik pengelolaan tanah yang baik sangat diperlukan dalam memanfaatkan tanah PMK untuk bidang pertanian.

Tanah aluvial umumnya berwarna kekelabu-kekelabuan sampai coklat tekstur tanahnya adalah liat berpasir dengan kandungan pasir kurang dari 50\%. Struktur pejal atau tanpa struktur, sedangkan konsistensinya keras waktu kering dan teguh waktu lembab. Tanah aluvial ditemukan diseluruh wilayah Indonesia yang tersebar sepanjang dataran, pelembahan, daerah cekungan dan sepanjang aliran sungai-sungai kecil dan besar.

Tanah gambut dalam taksonomi tanah didefinisikan antara lain sebagai tanah yang mengandung C-organik lebih dari $12 \%$ (bahan organik lebih dari 20\%) bila tanah tidak mengandung liat, atau C-organik lebih dari $18 \%$ (bahan organik lebih dari $30 \%$ ) bila tanah mengandung liat $60 \%$ atau lebih dan tebalnya lebih dari $40 \mathrm{~cm}$. bila kandungan liat antara 0-60\%, maka kandungan C-organik harus sebesar (12+ (\% liat $\times 0,1)) \%$ (Soil Survey Staff; 1998).

Berdasarkan uraian di atas penulis telah melaksanakan penelitian yang berjudul Pengaruh Berbagai Media Tanam terhadap Pertumbuhan dan Produksi Beberapa Varietas Tanaman Jagung. Gunakan template ini dengan cara copy and paste untuk kemudahan proses penulisan makalah anda. Penulisan istilah yang sangat spesifik khususnya dalam Bahasa Inggris menggunakan hurup italics. Memulai bab baru menggunakan dua spasi.

\section{TINJAUAN PUSTAKA}

\subsection{Morfologi Tanaman Jagung Second- Level Heading}

Menurut Warisno (1998) tanaman jagung merupakan salah satu jenis tanaman biji-bijian dari keluarga rumput-rumputan. Secara taksonomi diklasifikasikan sebagai berikut. 
Kingdom

Divisio

:Plantae

Sub Diviso

:Spermatopia

Class

Famili

:Angiospermae

:Monocotiyledoneae

Genus

:Graminae

Spesies

:Zea

:Zea mays

Tanaman jagung berakar serabut, menyebar kesamping dan kebawah sepanjang 25 cm (Tobing, 1991). Perakaran tanaman jagung terdiri dari akar-akar biji seminal yang tumbuh ke bawah pada saat berkecambah. Akar koronal yang yang tumbuh keatas dari jaringan batal setelah pulmula muncul dan akar udara (brance) yang tumbuh dari buku-buku di atas permukaan tanah. Akar- akar seminal terdiri dari akar radikal atau akar primer ditambah dengan jumlah akar lateral yang muncul sebagai akar adventitions pada dasar dari buku pertama di atas pangkal batang. Akar udara berfungsi dalam asimilasi dan juga sebagai pendukung untuk memperkokoh batang terhadap kerebahan. Apabila masuk kedalam tanah. Akar ini akan berfungsi juga membantu penyerapan unsur hara (Irfan, 1999).

Tanaman jagung umumnya tidak bercabang kecuali pada jagung manis sering tumbuh beberapa cabang (anakan) yang muncul pada pangkal batang. Panjang batang jagung pada umumnya berkisar antara $60 \mathrm{~cm}-300 \mathrm{~cm}$ atau lebih tergantung tife dan jenis jagung. Ruas bagian atas berbentuk silindirs dan ruas-ruas batang bagian bawah berbentuk bulat agak pipih. Tunas batang yang telah berkembang menghasilkan tajuk bunga betina (Rubatzky dan Yamaguchi, 1998).

Kedudukan daun tanaman ini distik (dua baris daun tunggal yang keluar dalam kedudukan berselang). Daun terdiri atas pelepah daun dan helaian daun. Daunnya berkisar antara 10-20 helai tiap tanaman. Epidermis daun bagian atas biasanya berambut halus. Kemiringan daun sangat bervariasi antara genotif dan kedudukan daun yang berkisar dari hampir datar sampai tegak (Fisher dan Goldsworthy, 1996).

Tanaman jagung termasuk Monoceous, tetapi bunga jantan dan betina letaknya terpisah. Bunga jantan dalam bentuk malai terletak dipucuk tanaman, sedangkan bungan betina pada tongkol yang terletak kira-kira pada pertengahan tinggi tanaman. Tepung sari dihasilkan malai 1-3 hari sebelum rambut tongkol keluar, rambut tongkol ini berfungsi sebagai kepala putik dan tangkai putik. Tepung sari mudah diterbangkan angin.

Apabila dalam tongkol terdapat 500 rambut tongkol maka inilah yang akan disebuki sehingga diperoleh 500 biji dalam satu tongkol dari hasil penyebukan. Karena letak bunga terpisah dan tepung saari mudah diterbangkan angin maka pembuahan berasal dari tanaman tetangga. Hal ini dikenal dengan penyerbukan silang. Pada tanaman jagung penyerbukan silang sebesar 95\% (Poehlman, 1987).

Biji jagung berkeping tunggal, berderet rapi pada tongkolnya. Pada setiap tanaman jagung ada satu tongkol, kadang-kadang ada yang dua. Setiap tongkol terdapat 10-14 deret biji jangung yang terdiri dari 200-400 butir biji jagung ( Suprapto dan Marjuki, 2005).

Buah biji jangung terdiri atas tongkol, biji dan daun pembungkus. Biji jagung mempunyai bentuk, warna dan kandungan endosperm yang bervariasi, tergantung pada jenisnya. Pada umumnya biji jangung tersusun dlam barisan yang melekat secara lurus atau berkelok-kelok dan berjumlah antara 8-20 baris biji. (Rukmana, 1997).

Tanaman jagung dapat tumbuh baik pada pH antara 6,5-7,0, tetapi masih cukup toleran pada tanah pada tingkat kemasaman yang relatif tinggi dan dapat beradap tasi pada keracunan AI. Tanah yang sesuai adalah tanah dengan tekstur remah, karena taanh tersebut bersifat porous sehingga memudahkan perakaran pada tanaman jagung. dengan pengerjaan tanah lebih sering selama pertumbuhannya, sehingga ariase dalam tanah berlangsung dengan baik. Air tanah yang berlebihan dibuang melalui saluran pengairan yang dibuat di antara barisan jagung (Anonimous, 2008).

Jagung umumnya ditanam didataran rendah, dilahan sawah pada hujan maupun sawah irigasi, tetapi terdapat juga di daerah dataran tinggi pada ketinggian 1000 m-1800 m di atas permukaan laut.

\subsection{Media Tanaman Jagung}

Produktifitas lahan adalah kemampuan tanaman yang diusahakan dalam suatu area berluasan tertentu dibawah suatu manajemen untuk emnghassilkan produksui dalam periode tertentu, yang dinyatakan dalam satun bobot perluasan perwaktu. Misalnya untuk produktifitas jagung dinyatakan sebagai ton/hektar permusim (Hanafiah, 2004).

Secara umum tanah dikelompokkan dalam dua golongan yaitu: 1) Tanah Endodoinamomorft yaitu tanah yang mempunyai sifat-sifat terutama kimiawinya yang indentik dengan bahan induknya atau terbentuk dari bahan residual, sepersi organosol (tanah gambut) di kawasan pantai Timur Sumatra Selatan, Jambi, Riau, Kalimantan, Papua. Andosol di dataran tinggi Indonesia dan Filipina; 2) Tanah Ektoddinamomorft, yang mempunyai sifatsifat yang tidak identik dengan bahan induknya. Contoh tanah golongan ini adalah Aluvial yang terletak di pinggiran sungai (Hanafiah, 2004).

Tanah gambut terbentuk dari bahan organik yang berasal dari tanaman, dimana setiap tanaman yang mati tidak melapuk 
sempurna sehingga bahan organik menumpuk lebih banyak dari bahan yang di lapukkan (Noor, 2001).

Soepardi (1983) menyatakan bahan komposisi penyusun tanah gambut antara lain $8 \%$ bahan organik, 2,5\% Nitrogen, $0,09 \%$ Fosfor, 0,08\% Magnesium dan $0,60 \%$ Sulfur.

Berdasarkan tingkat komposisinya gambut menjadi tiga kelompok yaitu: 1) Gambut Fibrik adalah gambut yang dicirikan dengan masih tingginya kandungan bahanbahan jaringan tanaman dan masih dapat dilihat dengan keadaan aslinya, perombakan bahan organik kurang dari 33\%. 2) Gambut Hemik adalah gambut yang sudah mengalami perombakan antara $33 \%$ hingga $66 \%$. 3) Gambut Saprik adalah dekomposisinya kurang dari $66 \%$ dan bersifat matang (Noor, 2001).

mempunyai kejenuhan basa tinggi sehingga dapat meningkatkan tanah gambut. Memiliki kandungan unsur hara makro dan mikro yang lengkap sehingga dapat juga berfungsi sebagai pupuk dan mempunyai kemampuan untuk memperbaiki sifat fisik dan kimia tanah. Salah satu bahan amelioran yang dapat digunakan adalah pupuk kandang dari kotoran hewan.

Tanah PMK masuk ke dalam struktur horizontal B di mana keadaan tanah bergumpal, gembur di bagian atas dan teguh bagian bawah.

Tanah ini memiliki sifat kimia kurang mantap dengan stabilitas agregat kurang, sehingga tanah ini mudah terkena erosi akibat gesekan air. Bentuk wilayah adalah datar sampai agak melandai oleh sebab itu sifat kimia dan fisiknya sangat bervariasi, banyak tergantung kepada bahan induknya dan letak topografinya. (Sarief, S. 1986).

Tanah aluvial di sebut juga sebagai tubuh tanah endapan, atau recent deposit, yang belum memiliki perkembangan profil yang baik. Tanah berwarna kekelabu-kekelabuan samapai kecoklat-coklatan.

Kandungan unsur haranya relatif kaya dan banyak ergantung dari bahan induknya. Permeabilitas umumnya lambat atau drainasenya rata-rata sedang dan cukup peka terhadap gejala erosi proses pembentukan tanah adalah alterasi lemak atau tanpa pembentukan (Sarief, 1986).

\section{METODOLOGI PENELITIAN}

Penelitian ini dilaksanakan di kota baru kecamatan keritang kabupaten indragiri hilir propinsi riau. Penilitian dilaksanakan di bulan febuari samoai bulan juni 2012 jadwal kegiatan dapat di lihat pada lampiran 1.

Apabila makalah adalah sebuah kajian

\subsection{Bahan dan Alat}

Bahan yang digunakan dalam penelitian ini adalah bibit jagung varietas simoleh, NT 10, N 35 dan mitro (deskripsi varietas jagung dapat dilihat pada lampiran 2). Pupuk yang di gunakan adalah pupuk urea, TSP, dan $\mathrm{KCL}$, dan lenis tanah yang di gunakan pada penelitian ini adalah tanah gambut. PMK dan tanah Aluvial. Tanah gambut pada penelitian ini di ambil di kota baru di parit 12, sedankan tanah PMK di ambil di daerah selensen dan tanah Aluvial di ambil di kota barau parit 03 kecamatan keritang.

Alat yang digunakan adalah cangkul, tugal, parang, meteran, tali palastik, garuk, timbangan, ember, pisau, amplop, lebelsampel, pelekat nama, hand sprayer, polibag, kertas lakmus, alat tulis, dan kalkulator.

\subsection{Metode Penelitian}

penelitian ini mengunakan rancangan Acak kelompok (RAK) dengan dua faktor perlakuan yaitu:

faktor 1: media tanam (v), terdiri dari 3 yaitu:

$$
\begin{array}{lll}
\text { T1 } & \text { :gambut } \\
& \text { T2 } & \text { :PMK } \\
& \text { T3 } & \text { :Aluvial }
\end{array}
$$

Faktor II: Varietas jagung (v), terdiri dari 4 taraf pelaksanan yaitu:

$$
\begin{array}{ll}
\text { V1 } & \text { : jagung manis } \\
\text { V2 } & \text { : NT } 10 \\
\text { V3 } & \text { : N } 35 \\
\text { V4 } & \text { : Mitro }
\end{array}
$$

Sehingga di peroleh 12 kombinasi perlakauan, dengan 3 kali ulanagan yaitu:

Tabel 1, kombinasi perlakuan penelitian

\begin{tabular}{|l|l|l|c|}
\hline \multirow{2}{*}{ Varietas } & \multicolumn{3}{|c|}{ perlakuan } \\
\cline { 2 - 4 } & T1 & T2 & T3 \\
\cline { 2 - 4 } & & V1T2 & V1T3 \\
V1 & V1T1 & V2T2 & V2T3 \\
V3 & V2T2 & V3T2 & V3T3 \\
V4 & V3T1 & V4T2 & V4T3 \\
\hline
\end{tabular}

Masing-masing perlakuan terdiri dari 3 ulangan seluruhnya berjumlah 36 unit percobaan. Data yang diperoleh di analisis secara stastik mengunakan uji $f$ (fisher'stst). Apabila $\mathrm{m}$ memperlihatkan hasil beda nyata, maka dilanjutakan uji BNJ paraf $5 \%$ penempatan masing-masing perlakuan dlakukan secara acak. Denah penemmpatan satuan percobaan dapat di lihat pada denah 3 .

\subsection{Pelaksanaan penelitian}

3.3.1. persiapan tanah 
Tanah diambil pada ketebalan sekitar $20 \mathrm{~cm}$, diasumsikan bahwa tanah bagian atas (top soil) tanah yang memilikikandungan unsur hara yang baik. Setelah tanah diambil ken\mudian di bersihkan dari kotoran akar dan gulma yang ada. Tanah di ambil sebanyak kebutuhan yaitu $12 \times 3$ polybag tiap polybag berisi tanah sekitar $7,5 \mathrm{~kg}$ untuk di masukan ke dalam masing-masing polybag.

\subsection{2.persiapan polybag}

Pengisian polybag di isi dengan tanah yang telah diayak mengunakan ayakan pasir. Pemberian perlakuan media tanam ialah dengan cara mencampur tanah dengan pupuk dasar. Masiang-masing polybag dipisahkan antara media satu dengan yang lainya.

\subsection{3.pemberian pupuk dasar}

Pemupukan dasar diberikan dengan takaran $200 \mathrm{~kg}$ urea (1,66 g/polybag) serta $50 \mathrm{~kg}$ $\mathrm{KCL}(0,42 \mathrm{~g} /$ polybag). Pupuk urea diberikan 3 tahap yaitu saat tanam, menjelang pembungaan, menjelang pengisian biji, pupupu TSP dan KCL diberikan sekalihus saat tanam (Adisarwanto,2002)

\subsection{4.penanaman}

Benih jagung dirndam terlebih dahulu dengan mengunakan air kelapa yang sudah tua selama 2 jam sebelum ditanam. Penanaman dilakukan dengan menugal sedalam $3-5 \mathrm{~cm}$. Dalam satu polybag di tanami 2 biji jaguang. Setelah bibit ditanami di lubang tanam lalu ditutup dengan lapisan tanah tipis.

\subsection{5.pemeliharan}

Untuk memperoleh pertumbuhan tanaman jagung yang baik di dilakukan pemeliharan tanaman yaitu penyulaman, pennjagaan, penyiraman, penyianagan, dan pembubunan serta pengendalian hama dan penyakit.

\begin{tabular}{|c|c|c|c|c|}
\hline \multirow{2}{*}{$\begin{array}{l}\text { Perlakuan } \\
\text { varietas }\end{array}$} & \multicolumn{3}{|c|}{ Tanah } & \multirow{2}{*}{$\begin{array}{l}\text { Rata- } \\
\text { rata }\end{array}$} \\
\hline & gambut & PMK & Aluvial & \\
\hline \multicolumn{5}{|c|}{ 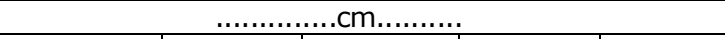 } \\
\hline Simoleh & 58,33 & 58,66 & 57,33 & \multirow{5}{*}{$\begin{array}{l}58,11 a b \\
57,88 a b \\
58,22 a \\
57,33 b\end{array}$} \\
\hline NT 10 & 57,66 & 58,33 & 57,66 & \\
\hline N 35 & 57,66 & 58,00 & 59,00 & \\
\hline mitro & 57,33 & 57,66 & 57,00 & \\
\hline Rata-rata & $57,75 a$ & $58,16 a$ & $57,75 a$ & \\
\hline
\end{tabular}

\subsection{6 penyiraman}

Penyiramana di lakukan satu kali sehari, dilakuakn pada sore hari atau tergantung kondisi linkungan. Penyiraman mengunakan gembor, jika hujan turun penyiraman tidak lakaukan.

\subsection{7 penyulaman}

Penyulaman dilakukan pada saat tanaman berumur satu minggu setelah tanam dengan menggunakan benih yang di sediakan untuk penyulaman.

\subsection{8 penjarangan}

Penjarangan dilakukan setelah tanam berumur 2 minggu dengan cara memotong salah satu tanaman yang pertumbuhanya kurang bagus dengan mengunakan pisau dan setiap lubang tanam ditinggalkan satu tanaman.

3.3.9penyiyangan dan pembumbunaaan Penyiyangan gulma yang ada di sekitar polybag maupiunyang ada dalam polybag. Dilakukan dengan menggunakkan sabit. Pembubunnan diloakukan pada waktu penyiyangan dan pemupukan.

3.3.10pengendelaian gulmadan penyakit Hama yang menyerang seperti penggerek batang dan penggerek daun. Hama ini di kendalikan dengan sanitasi lapang dan pemberian insektisida sintetik, furadan 3G di lubang tanam dan di pucuk tanaman saat berumur 4 mi8nggu setelah tanam.

\subsection{PEMANENAN}

Pemanenan jagaung seteelah tanaman jagung mencapai matang maksimal, dengan kadar air antara 300-35\% terlihat dari keadaan fisiknya.

\subsection{Pengamatan}

\subsubsection{Tinggi tanam $(\mathrm{cm})$}

Pengukuran tinggi tanam dilakukan setelah jagung berbungga atau akhir masa vegatatif yang di tanadai dengan munculnya bungga betina.

\subsubsection{Luas Daun}

Luas daun di hitung pda tanaman sudah berbungga. Daun yang di hitung adalah daun yang bagian tengah menggunakan meteran.

3.5.3 umur berbunga (HST)

Umur berbunga diamati saat semua tanaman telah berbungga.

jelaskan pada Bab Metodologi Penelitian tahapan yang dilakukan.

\section{HASIL DAN PEMBAHASAN}

\subsection{Tinggi tanaman (cm)}

Analisis sidik ragam menunjukan bahwa intraksi perlakuan media tanam dan varetas berpengarauh tidak nyata tyerhadap tinggi tanam, akan tetapi perlakuan media tanam pengaruh tidak nyata terhadap tinggi tanaman (lampiran 4a).hasial analisis stastikyang diuji lanjut dengan BNJ pada taraf 5\% dapat di lihat

pada tabel 2

Tabel 2.

Rata-rata pengaruh berbagai media tanah dan beberapa varietas Terhadap tinggi tanam.

\begin{tabular}{|l|l|l|}
\hline Perlakuan & Tanah & Rata- \\
\hline
\end{tabular}




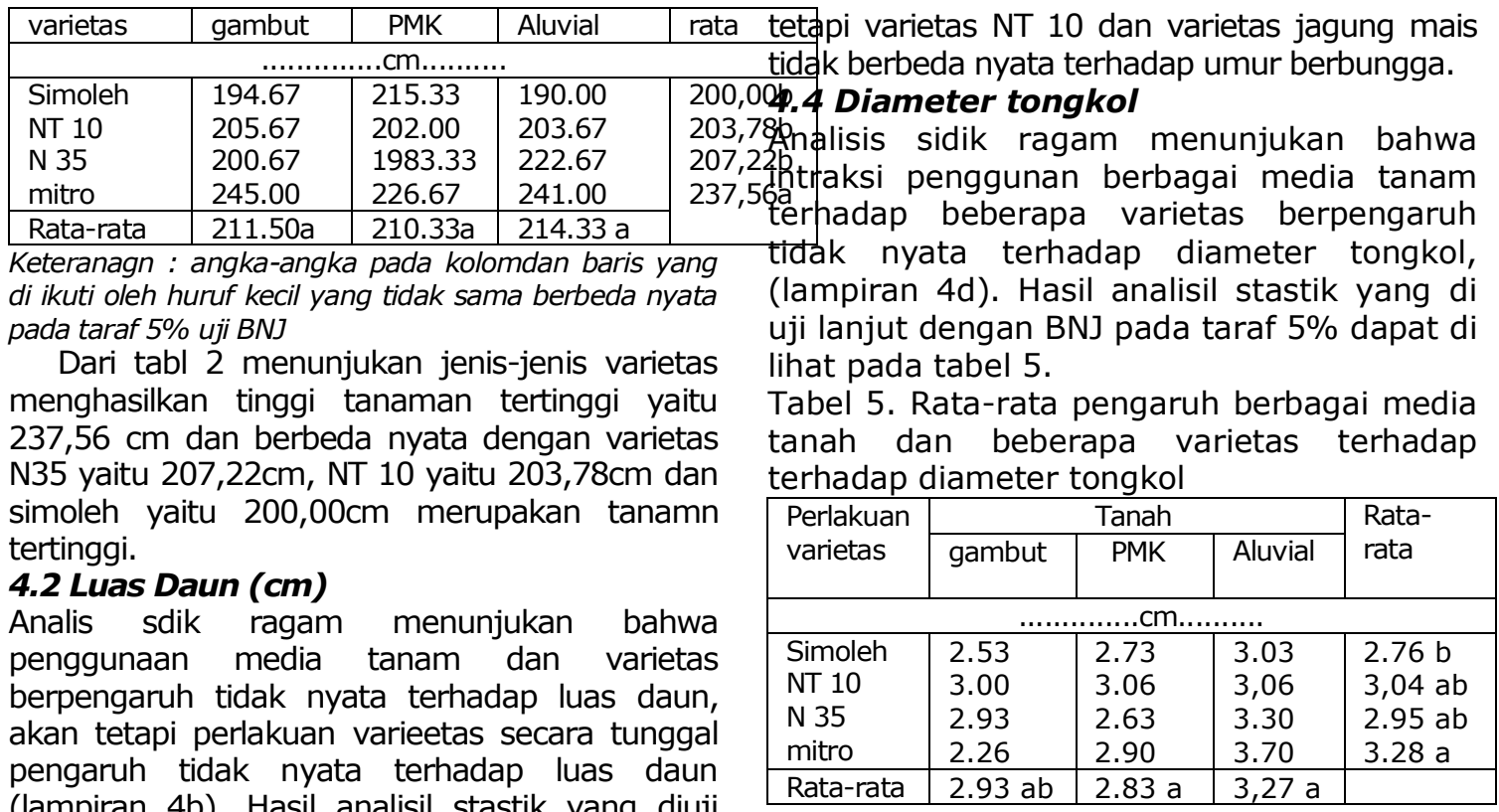
(lampiran 4b). Hasil analisil stastik yang diuji nlanjut dcebgan BNJ pada taraf $5 \%$ dapat di lihat pada tabel 3.

Tabel 3. Rata-rata pengaruh berbagai media tanah dan beberapa varietas terhadap luas daun.

Keterangan: angka-angka pada kolom dan baris yang diikuti oleh huruf kecil yang tidak sama berbeda nyata pada taraf 5\% UJI BNJ.

Dari tabel 5 menunjukan perlakuan

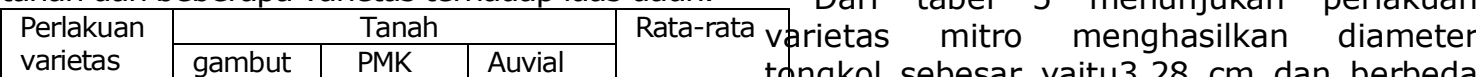
\begin{tabular}{|l|l|l|l|l|l} 
varietas & gambut & PMK & Auvial & tongkol sebesar yaitu3,28 cm dan berbeda
\end{tabular}

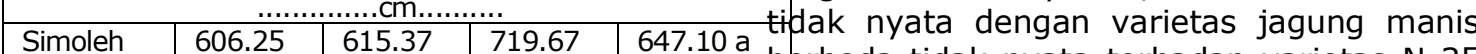
\begin{tabular}{|l|l|l|l|l|l}
\hline Simoleh & 606.25 & 615.37 & 719.67 & 647.10 a \\
NT 10 & 685.00 & 615.00 & 718.53 & 672.19 a berbeda tidak nyata terhadap varietas N 35 \\
\hline
\end{tabular} \begin{tabular}{l|l|l|l|l} 
N 35 & 700.33 & 630.00 & 734.23 & 688.19 a dan NT 10.
\end{tabular}

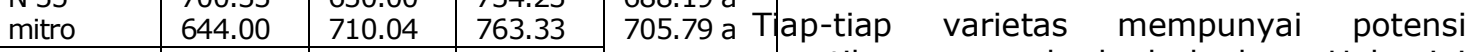
genetik yang berbeda-beda. Hal in Keterangan : angka-angka pada kolom dan baris yang dikuti oleh huruf kecil yang tidk sama berbeda nyata pada taraf $5 \%$ UJI BNJ

Dari tabel 3 menunjukan luas daun tertinggi diperoleh pada variertas mitro yaitu $705.79 \mathrm{~cm}$ dan berbeda tidak nyata dengan perlakuan varietas simoleh $(647.10 \mathrm{~cm})$, yang merupakan luas daun terendah. Luas daun tana man di pengaruhi oleh faktor internal faktor internal meliputi genetik dari varietas itu sendir, sedangkan faktor ekstrnal adalah linkungan yang meliputi penyinaran matahar, curah hujan suhu kelembaban dan kecepatan angin.

\subsection{Umur Berbunga (HST)}

Amalisis sidik ragam menunjukan bahwa tanamandan varetas pengaruh tidak nyata terhadap umur berbunga, perlakuan media tanam pengaruh tidak nyata terhadap umur berbunga, akan tetapi perlakuan varietas secara tunggal berpengaruh nyata terhadap umur berbunga, akan (lampiran 4c). Hasil analisis stastik yang di uji lanjut dengan BNJ pada taraf $5 \%$ dapat di lihat pada tabel 4 .

Keterangan :angka-angaka pada kolom dan baris yang diikuti oleh hurup kecil yang tidak sama berbeda nyata pada taraf $5 \%$ UJI BNJ

Dari tabel 4 menunjukan bahwa umur berbungga tercepat terdapat pada 58,22 HST yang merupakan umur berbungga terlama, akan mengakibatkan setiap varietas berbeda-beda sifatnya dalam pertumbuhan maupun produksi.satu varietas akn mampu meghasilkan potensi genetiknya, apabila di tanam pada kondisi lingkungan yang sesuai.

\subsection{Jumlah Biji per Tongkol}

Analisis sidik ragam menunjukan bahwa intraksi media tanam dan varietas berpengarauh tidak nyata terhadap jumlah biji per tongkol, perlakuan media tanam secara tunggal pengaruh tidak nyata terhadap jumlah biji, akan tetapi perlakuan varietassecara tunngal memberikan pengaruh yang nyata terhadap jumlah biji per tongkol (lampiran 4e). Hasil analisis stastik yang di uji lanjut dengan BNJ pada taraf 5\% dapat di lihat pada tabel 6.

T6abel 6. Rata-rata pengaruh berbagai media tanam dan beberapa varietas jagunga terhadap jumlah biji per tongkol.

\begin{tabular}{|c|c|c|c|c|}
\hline \multirow{2}{*}{$\begin{array}{l}\text { Perlakuan } \\
\text { varietas }\end{array}$} & \multicolumn{3}{|c|}{ Tanah } & \multirow[t]{2}{*}{ Rata-rata } \\
\hline & gambut & PMK & Aluvial & \\
\hline \multicolumn{5}{|c|}{$\ldots \ldots \ldots \ldots \ldots, \ldots m . \ldots \ldots \ldots$} \\
\hline Simoleh & 271.00 & 262.67 & 214.00 & $258.56 \mathrm{~b}$ \\
\hline NT 10 & 295.33 & 298.00 & 261.33 & $284.89 a b$ \\
\hline N 35 & 282.33 & 217.00 & 288.33 & $262.56 b$ \\
\hline Mitro & 287.67 & 342.67 & 369.00 & $332.89 a$ \\
\hline Rata-rata & $284.33 a$ & $279.92 \mathrm{a}$ & $289.92 \mathrm{a}$ & \\
\hline
\end{tabular}

Keterangan : angka-angka pada kolom yang 
diikuti oleh huruf kecil yang tidak sama berbeda nyata pada taraf 5\% UJI BNJ

dari tabel 6 menunjukan perlakaun varietas mitro menghasilkan jumlah biji terbesar yaitu 33.89 biji dan berbeda nyata dengan varietas simoleh yaitu 258.56 biji yang merupakan jumlah biji terendah, akan tetapi jumlah biji varietas N 35 tidak berbeda nyata dengan varietas $\mathrm{N} 10$ dan jagung manis.tejadinya perbedaan yang nyata antara varietas yang satu dengan vaeietas yang lain di sebabkan oleh faktor linkungan dan jenis varietas yang di gunakan.

\subsection{Produksi kering jagung kering pipilan per} tanaman (gram)

Analisis sidik ragam menunjukan bahwa intraksi media tanam dan varietas berpngaruh tidak nyata terhadap produksi kering. Perlakuan media tanaman secara tunggal pengaruh tidak nyata terhadap produksi kering,akan tetapi perlakuan antar varietas secara tunggal memberikan pengaruh nyata terhadap produksi kering (lampiran 4f). Hasil analisis statistik yang di uji lanjut dengan BNJ pada taraf 5\% dapat dilihat pada tabel 7 .

Tabel 7.pengaruh berbagai media tanah dan beberapa varietas jagung terhadap produksi kering.

Keterangn : Angka-angka pada kolom dan baris yang di ikuti oleh huruf kecil yang tidak sama bebeda nyata pada taraf 5\% UJI BNJ.

Dar tabel 7 menunjukan bahwa produksi kering tertinggi di peroleh pada varietas mitro yaitu $182.77 \mathrm{~g}$ dan berbeda nyata dengan varietas simoleh yaitu 91,00 yang merupakn produksi kering. Jenis varietas merupakan salah satu fakrtor yang mempengaruhi daya hasil jagung. Keampuan tanaman untuk mengahasilkan produksi ditentukan oleh faktor genetis, fakrtor linkungan dan intraksi sifat-safat genetis akan muncul secara utuh jika faktor lingkungan mendukung.

\section{KESIMPULAN DAN SARAN}

Berdasarkan penelitian yang di lakukan, maka dapatdi simpulkan bahwa:

Intraksi antara mediatanam dan beberapa varetas jagung tidak berpengaruh nyata terhadap pramenyer tinggi tanamaan, luas daun, umur berbungga, diameter tongkol, jumlah biji per tongkol peruduksi kering sereta bobot 1000 biji.

Pada penelitian ini tanah yang paling bagus adalah tanah aluvial dan jenis varietas terbaik yaitu varietas mitro baik pada masa pertumbuhan sampai ke produksi.

\section{UCAPAN TERIMA KASIH}

Pada kesempatan ini penulis mengucapkan terimakasih yang sebesr besarnya kepada bapak muhammad Arapah., SP,M,SI Bapak aswin Bovita,SP selaku pembimbing I dan pembimbing II atas ilmu yang di berikan.

\section{DAFTAR PUSTAKA}

Annonimous.2008 Badab pusat statistik Harvested Area, yield rate and production of mayze by province, 2006-2007. www,bps.go.id. dikutip 28 februari 2008.

Rukmana. (1997). usaha tani jagung. yogyakarta.

Irfan, m.1999.respon tanaman jagung (zea mays L) terhadp pengolahan tanah dan kerapatan tanah pada tananh andisol dan ultisol. Pasca sarjana universitas utara. Medan. Hal 7-13

Soepardi. G. 1983. Sifat dan ciri Tanah. Jurusan ilmu tanah. Insitut pertanian

Sarief, S. 1986. Ilmu tanah pertanian. Pustaka buana bandung.

\begin{tabular}{|l|l|l|l|l|}
\hline \multirow{2}{*}{$\begin{array}{l}\text { Perlakuan } \\
\text { varietas }\end{array}$} & \multicolumn{3}{|c|}{ Tanah } & Rata-rata \\
\cline { 2 - 4 } & gambut & \multicolumn{1}{|c|}{ PMK } & Aluvial & \\
\hline \multicolumn{4}{|c}{$\ldots \ldots \ldots \ldots . . \mathrm{cm} \ldots \ldots \ldots . .}$. \\
\hline Simoleh & 95.00 & 83.00 & 95.00 & $91.00 \mathrm{~b}$ \\
NT 10 & 170.67 & 131.67 & 121.33 & $141.22 \mathrm{a}$ \\
N 35 & 79.33 & 96.67 & 126.67 & $100.89 \mathrm{~b}$ \\
Mitro & 173.33 & 158.33 & 216.67 & $182.77 \mathrm{a}$ \\
\hline Rata-rata & $129.58 \mathrm{a}$ & $117.41 \mathrm{a}$ & $139.91 \mathrm{a}$ & \\
\hline
\end{tabular}

\subsection{Bobot 1000 biji}

Analisis sidik ragam menunjuykan bahwa intraklsi media tanam dan varietas berpengaruh tidak nyata terhadap bobot 1000 biji, perlakuan media tanam secara tunggal pengaruh tidak nyata terhadap bobot 1000 biji akan tetapi perlakuan antar varietas secara tunggal memberikan pengaruh nyata terhadap bobot 1000 biji (lampiran $4 \mathrm{~g}$ ). Analisis stastik yang di uji 
lanjut dengan BNJ pada taraf $5 \%$ dapat di lihat pada tabel 8.

Berdasarkan penelitian yang di lakukan, maka dapatdi simpulkan bahwa:

Intraksi antara mediatanam dan beberapa varetas jagung tidak berpengaruh nyata terhadap pramenyer tinggi tanamaan, luas daun, umur berbungga, diameter tongkol, jumlah biji per tongkol peruduksi kering sereta bobot 1000 biji.

Tabel 8 pengaruh berbgai media tanah dan beberapa varietas jagung terhadap 1000 bobot biji.

\begin{tabular}{|c|c|c|c|c|}
\hline \multirow{2}{*}{$\begin{array}{l}\text { Perlakuan } \\
\text { varietas }\end{array}$} & \multicolumn{3}{|c|}{ Tanah } & \multirow{2}{*}{ Rata-rata } \\
\hline & gambut & PMK & Aluvial & \\
\hline \multicolumn{5}{|c|}{$\ldots \ldots \ldots \ldots \ldots . . .6 m \ldots \ldots \ldots$} \\
\hline Simoleh & 220 & 196.6 & 250 & $222.2 b$ \\
\hline NT 10 & 233.3 & 236.6 & 246,6 & $238.8 b$ \\
\hline N 35 & 230 & 206.6 & 246,6 & $227.7 b$ \\
\hline mitro & 270 & 280 & 263,3 & $271.1 \mathrm{a}$ \\
\hline Rata-rata & $238.32 a$ & $229.95 a$ & $251,62 a$ & \\
\hline
\end{tabular}

Keterangan : Angka-angka pada kolom dan baris yang diikuti oleh huruf kecil tidak sama berbeda nyata pada taraf 5\% UJI BNJ.

Dari tabel 8 menunjukan bahwa bobot 1000 biji tertinggi diperoleh pada varietas mitro yaitu $271,1 \mathrm{~g}$ dan berbeda nyata dengan varietas simoleh yaitu 222,2 g yang merupakan bobot 1000 biji terendah, akan tetapi varietas N35 jagung manis dan NT 10 berbeda tidak nyata terhadap bobot 1000 biji, bobot 1000 biji merupakan minefestasi dari kemampuan tanaman untuk menghaslilkan produksi dalam bentuk karbohidrat. 